\title{
HUTANG NEGARA DALAM REFORMA AGRARIA STUDI IMPLEMENTASI MANDAT 9 JUTA HEKTAR TANAH INDONESIA
}

\author{
The State's Responsibility on Agrarian Reform Study of the Implementation of the \\ Mandate of 9 Million Hectares of Land in Indonesia
}

\author{
Arditya Wicaksono ${ }^{1}$ dan Yudha Purbawa ${ }^{1}$ \\ 'Peneliti Pusat Penelitian dan Pengembangan \\ Kementerian Agraria dan Tata Ruang/Badan Pertanahan Nasional \\ Jl. H. Agus Salim No. 58 Jakarta Pusat \\ Email: arditya_wicaksono@yahoo.co.id
}

\begin{abstract}
Discussion of agrarian reform is interesting especially on its factual implementation that is fully dynamics and not just a promise to redistribute nine million hectares of land. The existing concept needs to be reevaluated and re-discussed. Reorganizing inequality of land redistribution requires compatible and comprehensive rules. This paper uses a case study approach, giving an overview of the challenges to be addressed in order to implement agrarian reform properly. Cross-ministries coordination is inevitable, since in real practice access reform cannot be implemented linearly but requires holistic and systematic integrations with other ministries.
\end{abstract}

Keywords: Agrarian Reform and policy implementation.

Intisari: Diskusi reforma agraria memang menarik terlebih implementasi faktualnya yang penuh dinamika tidak sekedar janji untuk meredistribusi sembilan juta hektar. Konsep yang ada perlu diperdebatkan kembali. Menata ulang ketimpangan dalam redistribusi tanah butuh aturan yang kompatibel dan komprehensif. Tulisan ini menggunakan pendekatan studi kasus untuk memberikan gambaran kendala dan tantangan yang harus diurai agar hutang negara dalam reforma agraria menjadi sebuah kebijakan yang terimplementasi secara tepat. Sinergi dengan lintas kementerian mutlak diperlukan sebab secara nyata akses reform tidak bisa bergerak secara linier tetapi memerlukan integrasi yang holistik dan sistematis dengan kementerian lain.

Kata kunci: Reforma Agraria dan implementasi kebijakan.

\section{A. Pendahuluan}

Salah satu rumusan dari sembilan agenda prioritas (Nawacita) yang merupakan implementasi dari Visi Misi Pemerintahan Jokowi-JK adalah meningkatkan kualitas hidup manusia Indonesia melalui peningkatan kualitas pendidikan dan pelatihan dengan program Indonesia Pintar, serta peningkatan kesejahteraan masyarakat dengan program
Indonesia Kerja dan Indonesia Sejahtera dengan mendorong landreform dan program kepemilikan tanah seluas 9 juta hektar, program rumah kampung deret atau rumah susun murah yang disubsidi serta jaminan sosial untuk rakyat di tahun 2019. ${ }^{1}$

1 Agenda Nawacita Presiden Joko Widodo dan Yusuf kalla saat terpilih menjadi Presiden RI 2014-2019 
Tonggak utama pelaksanaan landreform itu sendiri sebenarnya sudah dimulai sejak terbitnya Undang-undang Nomor 1 Tahun 1958 tentang Penghapusan Tanah-Tanah Partikelir, sebagai upaya untuk mengakhiri sistem hukum tanah kolonial. Terbentuknya Undang-Undang Nomor 5 Tahun 1960 tentang Pokok-Pokok Agraria (UUPA) merupakan program revolusi di bidang agraria yang disebut Agrarian Reform Indonesia yang meliputi 5 program (Panca Program), yaitu :

1. Pembaharuan hukum agraria, melalui unifikasi hukumyang berkonsepsi nasional dan pemberian jaminan kepastian hukum;

2. Penghapusan hak-hak asing dan konsesikonsesi kolonial atas tanah;

3. Mengakhiri penghisapan feodal secara berangsur-angsur;

4. Perombakan pemilikan dan penguasaan tanah serta hubungan-hubungan hukum yang bersangkutan dengan penguasaan tanah dalam mewujudkan pemerataan kemakmuran dan keadilan;

5. Perencanaan persediaan dan peruntukan bumi, air dan kekayaan alam yang terkandung di dalamnya serta penggunaanya secara terencana, sesuai dengan daya dukung dan kemampuannya.

Program yang ke 4 (empat), lazim disebut program landreform. Bahkan keseluruhan program Agrarian Reform Indonesia tersebut seringkali disebut program landreform. Maka ada sebutan lendreform dalam arti luas dan landreform dalam arti sempit. ${ }^{2}$

2 Pada masa orde baru, Menteri Urusan Agraria diperkecil menjadi Direktorat Jenderal di bawah Menteri Dalam Negeri. Di tahun 1968, program redistribusi tanah lebih dari 450 ribu hektar telah diredistribusikan untuk 500 ribu keluarga di Jawa. Penerima reforma agraria menerima tanah kurang dari satu hektar. Menurut Utrecht angka tersebut tidak bisa diandalkan karena tidak memperhitungkan berapa jumlah tanah yang terdistribusi dan
Pembaruan agraria merupakan terjemahan dari agrarian reform (reforma agraria), yang dalam pengertian terbatas dikenal sebagai landreform, dimana salah satu programnya yang banyak dikenal adalah redistribusi (pembagian) tanah (Bonnie Setiawan 1997, 3) sayangnya sampai saat ini upaya mereformasi penguasaan dan pemilikan tanah mengalami hambatan, sehingga Kementerian ATR/BPN mencatat seperti gambar 1 berikut:

Gambar 1. Skema Penguasaan dan Pemilikan Tanah di Indonesia

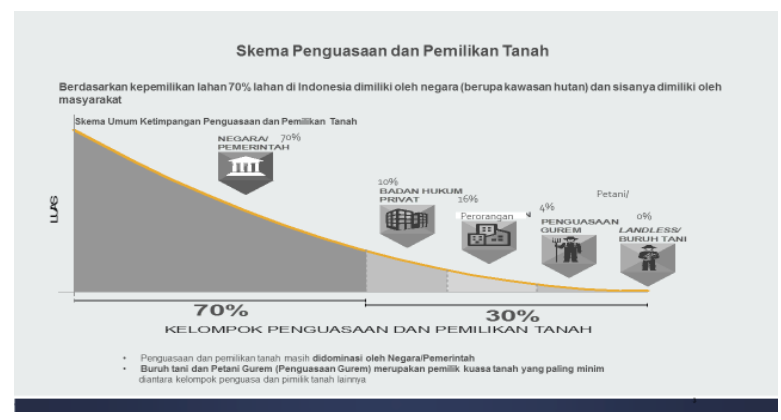

Sumber: Paparan Sofyan A. Djalil, disampaikan pada Seminar Nasional dalam Rangka Hari Agraria dan Tata Ruang Nasional Jakarta, 25 Oktober 2016.

Kepemilikan dan penguasaan tanah yang sempit dan timpang di desa bukan sesuatu yang baru. Sejak awal abad ke 2o Pemerintah Belanda telah menyadari hal ini melalui survei yang dilakukan pada tahun 1903. Hasilnya hampir separuh petani menguasai tanah kurang dari o,5 ha (Mubyarto, 1978). Jumlah tanah yang sangat terbatas serta pertumbuhan penduduk yang tiada kontrol telah memicu persoalan yang kompleks untuk diselesaikan. Persoalan ketimpangan penguasaan dan pemilikan tanah menjadi beban negara untuk bisa dikatakan sejahtera, sebab segenap aktivitas manusia

telah diambil alih lagi oleh pemilik lama dengan terbuka atau tersembunyi. Pada era ini lembaga pertanahan lebih bersifat administrasi semata sehingga redistribusi tanah hanya dimaknai sebatas bagi-bagi tanah. Hilang esensi ruhnya bahwa tanah merupakan sumber kehidupan. Pada akhir era orde baru kembali bangkit kajian reforma agraria dengan maksud memperbaiki tatanan reforma agraria yang lebih baik bukan sekedar administrasi. 
memerlukan tanah sebagai media. Kondisi ini yang memicu konflik agraria baik berupa perselisihan tanah di tingkat rumah tangga petani, meningkatnya penguasaan tanah skala besar, konversi penggunaan tanah yang tidak terencana, tata ruang yang tidak konsisten dan tumpang tindih. Hal ini tidak hanya berdampak pada masyarakat secara langsung tetapi juga pada program pemerintah seperti ketahanan pangan, perumahan rakyat, dan lingkungan hidup (Shohibuddin dan Salim, 2012), maka menjadi suatu keniscayaan untuk melaksanakan reforma agraria sebagai upaya mengatasi ketimpangan penguasaan dan pemilikan tanah sebagai sumber utama permasalahan, yang pada akhirnya bermuara pada pengurangan kemiskinan.

Sumberdaya manusia di suatu negara umumnya sebanding dengan kemajuan negara tersebut, apalagi ditunjang oleh sumber daya alam yang dimiliki oleh negara yang didistribusikan secara adil dan merata. Sebaliknya akan menimbulkan masalah apabila pemerataan pemilikan dan penguasaannya tidak diperhatikan dan ditujukan untuk kesejahteraan rakyat. Pengalaman sejarah dunia mencatat, ketidakseimbangan pemilikan tanah dan sumber-sumber (Agraria) yang paling banyak menimbulkan masalah dan penyengsaraan rakyat. Sebaliknya indikasi sejahtera tidaknya rakyat di suatu negara ditentukan oleh adanya pemerataan pemilikan dan penguasaan agraria. Lipton, menteorisasi dan membuat taksonomi praktek Landreform di beberapa negara yang sedang berkembang. Ia mendefinisikan landreform sebagai perundang-undangan (legislasi) yang diperuntukkan mendistribusi kepemilikan klaim-klaim atas tanah atau hak-hak atas tanah pertanian dan dijalankan untuk memberi manfaat pada kaum miskin dengan cara meningkatkan status kekuasaan dan pendapatan absolut atau relatif mereka
(Michael Lipton 2009, 161).

Pengaturan tentang penguasaan pemilikan tanah telah disadari sejak berabadabad lamanya oleh negara-negara di dunia. Perombakan dan pembaharuan struktur keagrarian terutama tanah, dilakukan untuk meningkatkan kesejahteraan rakyat terutama rakyat tani yang semula tidak memiliki lahan garapan untuk memiliki tanah, oleh Parlindungan dikatakan bahwa negara yang ingin maju harus mengadakan landreform (Parlindungan, 1980).

Berdasarkan laporan kekayaan global yang diterbitkan oleh Credit Suisse, jumlah penduduk miskin di Indonesia tahun 2017 adalah sebesar 28,o1 juta jiwa (10,8\%) dan sebesar 49,30\% sumberdaya ekonomi Indonesia dikuasai hanya oleh 1\% penduduk Indonesia. Badan Pusat Statsitik (BPS) mencatat pada Maret 2016 angka indeks gini rasio umum sebesar 0,39\%, dan gini rasio penguasaan tanah sebesar o,59\%, korporasi menguasai hampir 60\% lahan perkebunan sawit di Indonesia (Direktorat Jenderal Penataan Agraria, 2017).

Reforma agraria diharapkan mampu menjadi solusi persoalan ketimpangan dan penguasaan tanah. Untuk menjadikan reforma agraria sebagai landasan pembangunan Indonesia, maka pelaksanaan reforma agraria perlu didasari oleh struktur hukum yang kuat dan komprehensif, agar dapat mewujudkan keadilan. Dalam hukum agraria, struktur hukum terkait dengan segala sesuatu yang berhubungan dengan aspek penguasaan dan pemilikan tanah dan atau sumber daya alam. Pada tataran kebijakan, ketimpangan struktur penguasaan dan pemilikan tanah dan sumber daya alam lainnya, justru lebih banyak disebabkan oleh tidak adanya tafsir resmi atas asas hak menguasai negara terhadap bumi, air dan kekayaan alam yang terkandung di dalamnya sebagaimana ditegaskan dalam Pasal 33 ayat (3) UUD 1945 (Ida Nurlinda 2015, 9). 
Tafsir "Hak Menguasai Negara” merupakan penguasaan negara atas sumberdaya agraria (SDA) yang disebut dengan hak menguasai negara (HMN) merupakan wewenang yang diperoleh negara berdasarkan prinsip atribusi dari UUD 1945. Dalam konsepsi Hukum Tanah Nasional, HMN merupakan pelimpahan hak publik berupa amanat untuk mengelola dari Hak Bangsa sebagai hak yang tertinggi kepada negara. Atas dasar pelimpahan tersebut, negara berwewenang untuk merumuskan kebijakan, melakukan pengaturan, pengurusan, pengelolaan dan pengawasan terhadap SDA. Untuk menghindari kesewenang-wenangan dari HMN, maka kewenangan negara dibatasi oleh 3 (tiga) hal yaitu: oleh tujuan dari HMN itu sendiri yaitu untuk mencapai sebesar-besar kemakmuran rakyat; oleh hak perseorangan dan badan hukum; serta oleh hak ulayat masyarakat adat (Julius Sembiring 2016).

Berbagai penelitian dan kajian terkait reforma agraria di Indonesia sudah pernah dilakukan oleh Pusat Penelitian dan Pengembangan (Puslitbang) Kementerian Agraria dan Tata Ruang/Badan Pertanahan Nasional sendiri. Puslitbang pernah melakukan kajian mengenai model redistribusi tanah dalam skala kecil pada tahun 2005; Penelitian mengenai pengaturan penguasaan tanah batas maksimum dan minimum penguasaan dan pemilikan tanah pada tahun 2006; Penelitian kondisi awal sosial ekonomi masyarakat penerima program pembaruan agraria nasional pada tahun 2007; Penelitian selektifitas \& penetapan kriteria kemiskinan subyek reforma agraria pada tahun 2008 dan 2009; dan Kajian mengenai reforma agraria dalam sejarah dan implementasinya pada tahun 2011 (Puslitbang, 2017). Dalam kajian tahun 2011 tentang sejarah dan implementasi reforma agraria, merupakan kajian studi literatur yang menggunakan data sekunder, dan menghasilkan berbagai deskripsi tentang sejarah timbulnya reforma agraria, deskripsi reforma agraria di negara lain, dan deskripsi reforma agraria di Indonesia, namun belum pernah ada penelitian maupun kajian yang dilakukan untuk melihat bagaimana implementasi terhadap mandat 9 juta hektar tanah reforma agraria di Indonesia, dimana mandat ini merupakan salah satu dari Program Nawacita Pemerintahan Republik Indonesia pada saat ini.

Berdasarkan pada data dan fakta tersebut di atas, maka tulisan ini hendak mengkaji tentang bagaimana implementasi pelaksanaan reforma agraria di Indonesia terkait dengan program nawacita Pemerintah tentang Reforma Agraria terhadap 9 juta hektar tanah? dengan melihat studi kasus pada beberapa daerah di Indonesia. Selain itu kasus-kasus persoalan yang muncul dimaksudkan untuk menggambarkan bagaimana implementasi pelaksanaan reforma agraria di Indonesia dengan melihat studi kasus pada beberapa daerah terkait dengan program nawacita Pemerintah.

\section{B. Reforma Agraria dan Landreform}

Istilah reforma agraria atau agrarian reform banyak digunakan oleh kalangan akademis bahkan Perserikatan Bangsa-Bangsa (PBB) atau United Nation (UN). Untuk makna yang lebih luas dibanding landreform, PBB atau UN membedakan landreform dengan reforma agraria dalam (Risnarto 2008, 18) sebagai berikut:

"Landreform refers to the integral reforms of tenure production and supporting service structure to eliminate obstacles to economic and social development arising ot of defects in the agraria structure, by redistribution of wealth, opportunity and power, as manifest in the ownership and control of lan, water and other resources" 
"Agraria reform to cover all aspect of institutional development including landreform, tenure production and supporting service structure and related institutions, such as local government, public administration in rural areas, rural education and rural social welfare institutions, and so forth"

Reforma agraria atau pembaruan agraria sebagai suatu gagasan atau ide yang kemudian diwujudkan dalam pelaksanaan suatu kebijakan, mengalami perubahan dan perkembangan baik mengenai isinya, sifatnya, tujuannya, maupun mengenai konseptualisasinya secara ilmiah, namun intinya tetap sama yaitu bahwa pembaruan agraria selalu berinti redistributive landreform $(R L R)$ yang artinya penataan kembali sebaran penguasaan tanah demi kepentingan petani kecil, penyakap, dan buruh tani tak bertanah (tunakisma). Dalam paket RLR kemudian dimasukkan langkah-langkah komplementer seperti penyediaan kredit, pendidikan dan pelatihan, teknologi, penyuluhan, penyesuaian struktur pasar, dan lain sebagainya, paket lengkap ini yang diberi istilah Agrarian Reform atau Pembaruan Agraria/Reforma Agraria (Gunawan Wiradi, 2000).

Kuhnen memberi pengertian reforma agraria a bundle of measures for overcoming the obstacles to economic and social development that based on shortcomings in the agrarian structure. Pendapat Kuhnen tersebut menitikberatkan pada fungsi reforma agraria untuk mengatasi hambatan dalam pembangunan ekonomi dan sosial yang didasarkan pada kelemahan struktur agraria itu sendiri. Di Indonesia, kelemahan struktur agraria berupa ketimpangan struktur penguasaan, pemilikan, penggunaan dan pemanfaatan tanah dan sumber daya alam. Di mana korporasi atau pemilik modal memiliki akses yang besar dibandingkan masyarakat yang tinggal di sekitar sumberdaya alam (Ida Nurlinda 2015).

Menurut Winoto (2009), reforma agraria atau pembaruan agraria bukanlah proyek bagibagi tanah, melainkan suatu program terpadu yang diorientasikan pada upaya perwujudan keadilan sosial dan peningkatan kesejahteraan rakyat melalui revitalisasi pertanian dan aktivitas ekonomi pedesaan secara menyeluruh, hal ini mencakup 2 komponen yaitu: Pertama adalah redistribusi tanah untuk menjamin hak rakyat atas sumber-sumber agraria; Kedua, upaya pembangunan lebih luas yang melibatkan multipihak untuk menjamin agar aset tanah yang diberikan dapat berkembang secara produktif dan berkelanjutan. Komponen pertama disebut asset reform, sedangkan yang kedua disebut access reform. Hal yang sama diungkapkan pula oleh Ferry Mursyidan Baldan, mengatakan bahwa program reforma agraria adalah untuk memberi kepastian hak atas tanah, bukan bagi-bagi tanah atau sertifikat (Ramadhiani, 2016).

Menurut (Risnarto 2008, 248) pembaruan agraria atau reforma agraria pada dasarnya merupakan konsep landreform dalam arti penataan kembali struktur penguasaan pemilikan tanah yang lebih adil. Dukungan sarana dan prasarana yang memungkinkan petani memperoleh akses ke sumber ekonomi di wilayah pedesaan yang secara matematis dapat digambarkan Reforma Agraria = Landreform + Access Reform.

Pelaksanaan Redistribusi Tanah Obyek Landreform (TOL) bertujuanuntukmemperbaiki keadaan sosial ekonomi penggarap dengan cara mengadakan pembagian tanah pertanian yang adil dan merata sebagai sumber penghidupan rakyat tani sekaligus kepastian hak atas tanah hasil redistribusi tanah obyek landreform. Tanah Obyek Landreform (TOL) adalah tanah yang karena ketentuan landreform dan/atau tanah yang telah ditegaskan menjadi obyek landreform untuk selanjutnya diredsitribusikan 
kepada petani penggarap. Adapaun tanah yang termasuk kedalam obyek landreform adalah sebagai berikut: bagian-bagian selebihnya dari batas maksimum dan absentee yang karena hukum menjadi tanah obyek landreform; tanahtanah swapraja dan bekas swapraja yang telah beralih kepada negara; tanah-tanah partikelir; dan tanah-tanah lain yang dikuasai langsung oleh negara (Kementerian ATR/BPN, 2016).

Landreform di Indonesiamengalamipasang surut seirama dengan perkembangan jaman. Landreform mencapai puncaknya antara tahun 1962- 1964, kemudian perubahan konstelasi politik Indonesia pasca 1965, menyebabkan pula reforma agraria surut, namun bukan hilang, tetapi mengalami pergesaran. Tanahtanah yang akan diredistribusikan (dibagikan) kepada petani penggarap pada awalnya berasal dari tanah-tanah yang terkena ketentuan landreform, tanah kelebihan dari batas maksimum dan tanah absentee, bergeser menjadi tanah-tanah yang dikuasai langsung oleh negara. Program landreform sendiri telah menyusut menjadi kegiatan redistribusi tanah baik secara langsung kepada petani penggarap maupun melalui program transmigrasi, Perkebunan Inti Rakyat/Nucleus Estate Small holders (PIR/NES), PIR-Trans dan sebagainya. ${ }^{3}$

Secara fisik, sampai tahun 1961-2005, telah dibagikan tanah obyek landreform di seluruh Indonesia seluas lebih kurang 1.159.527,27

3 Kondisi ini menurut penulis dikarenakan setiap pergantian era ada kecenderungan mengganti program dengan yang baru tanpa melakukan kajian secara obyektif, sebab transmigrasi, PIR dan program tersebut hakekatnya lebih mendayaguna masyarakat secara lebih baik karena masyarakat yang tidak memiliki akses diberi kesempatan memiliki dan dekat dengan sumber-sumber agraria. Idealnya dengan terbukanya akses masyarakat terhadap tanah secara prinsip berdampak secara langsung, kedepan perlu dicarikan strategi apa yang bisa untuk mencari nilai tambah berdasarkan kharakteristik di wilayah, meski kegiatan tersebut memiliki jangka waktu tertentu.
Hektar kepada 1.510.762 Kepala Keluarga dengan rata-rata luasan 0,5 Hektar (www.bpn.go.id). Ditinjau dari segi tujuan akhir landreform yaitu peningkatan taraf hidup atau kesejahteraan petani penerima tanah, dapat dikatakan belum seperti yang diharapkan. Faktor penghambat dapat diidentifikasi sebagai berikut: (a) rendahnya dukungan politik, stigma bahwa ideologi landreform adalah kiri; ${ }^{\text {(b) kurangnya }}$ penegakan hukum; (c) tidak tersedianya biaya, data dan informasi yang memadai (c) peraturan perundang-undangan yang tidak secara jelas dan tegas mengatur; (d) lemahnya lembaga pelaksana dan kualitas sumberdaya manusia.

Presiden telah menetapkan Rencana Kerja Pemerintah tahun 2017, dalam Perpres nomor 34 tahun 2016, yang di dalamnya terkandung Prioritas Nasional Reforma Agraria. Program-Program prioritas reforma agraria adalah: (1) penguatan kerangka regulasi dan penyelesaian konflik-konflik agraria; (2) penataan penguasaan dan pemilikan TanahTanah Obyek Reforma Agraria (TORA); (3) pemberian kepastian hukum dan legalisasi atas TORA; (4) pemberdayaan masyarakat untuk memperbaiki tata guna tanah dan membentuk kekuatan-kekuatan produktif baru; dan (5) pembentukan kelembagaan pelaksana reforma agraria di Pemerintah Pusat dan Daerah.

4 Makna stigma kiri dari kata Landreform merupakan bentuk Stereotipe pemerintah era itu, menilai terhadap seseorang/kelompok hanya berdasarkan persepsi terhadapkelompok di mana orang tersebut dapat dikategorikan Stereotipe, merupakan jalan pintas yang dilakukan secara intuitif oleh manusia untuk menyederhanakan hal-hal yang kompleks dan membantu dalam pengambilan keputusan secara cepat namun, seringkali dijadikan alasan untuk melakukan tindakan diskriminatif. Sebagian besar beranganggapan bahwa segala bentuk stereotipe adalah negatif. Stereotipe jarang sekali akurat. Kondisi ini seringkali terjadi di Indonesia sebagai akibat proses transformasi politik yang tidak lancar sehingga memunculkan konflik zero-sum disetiap akhir dan awal pergantian pemerintahan. 
Tantanganutama pemerintah dalam reforma agraria saat ini adalah ketimpangan ekonomi, masalah ketimpangan ini menjadi persoalan utama di banyak pemerintahan negara pasca kolonial dan semuanya berusaha menurunkan ketimpangan, serta mewujudkan pemerataan pendapatan, kekayaan dan pengeluaran. Ketimpangan adalah hasil dari pembangunan yang tidak adil dan merata, terutama karena semakin luas dan dalamnya keterlibatan penduduk dan wilayah di Indonesia dalam produksi, sirkulasi dan konsumsi komoditaskomoditas global, dan diatur dengan suatu pembagian kerja secara internasional yang terus diperbaharui. Mulanya, dipercayai pertumbuhan ekonomi menghasilkan ketimpangan yang perlu untuk mendorong pasar berinvestasi lebih banyak, termasuk kemajuan teknologi produksi dan peningkatan sumberdaya manusia Noer Fauzi (2016). Reforma Agraria diharapkan mampu dijadikan solusi komprehensif dalam mengurangi kemiskinan dan kesenjangan sosial yang terjadi di masyarakat Indonesia. Secara teori, reforma agraria berfungsi sebagai penataan ulang sumber-sumber agraria dan penguatan sendi-sendi perekonomian rakyat, sertipikat tanah dijadikan dasar untuk memicu gerak perekonomian warga. berikut skema pelaksanaan reforma agraria di Indonesia terkait 9 juta Hektar tanah yang tertuang dalam Rencana Pembangunan Jangka Menengah Nasional (RPJMN) seperti pada gambar 2.

Gambar 2. Skema Reforma Agraria dalam RPJMN

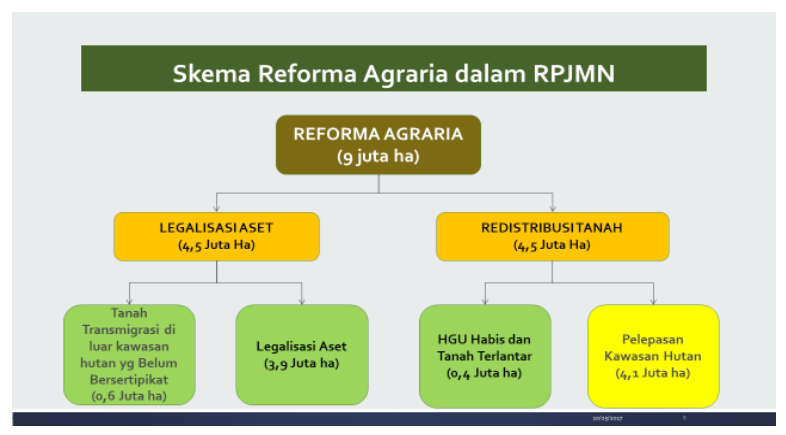

Sumber: Roadmap TORA Kementerian Agraria dan Tata Ruang/BPN
Bersumber dari skema tersebut Kementerian ATR/BPN diberi beban untuk melaksanakan percepatan sertipikasi tanahtanah di Indonesia, demi mewujudkan reforma agraria terhadap 9 juta Hektar tanah.

\section{Implementasi Reforma Agraria}

Reforma agraria adalah kebijakan yang harus dilakukan oleh negara, hal ini merupakan visi Pemerintah saat ini yang menegaskan bahwa kemanfaatan tanah sebagai kemakmuran dan ketentraman masyarakat. Reforma agraria memerlukan proses implementasi untuk mencapai suatu tujuan, ini baru dapat dimulai jika tujuan reforma agraria ditetapkan, program-program pelaksanaan telah dibuat dan dana telah dialokasikan untuk pencapaian tujuan kebijakan (Amir Santoso 1988,5). Implementasi kebijakan dapat diartikan sebagai proses pelaksanaan keputusan yang dibuat oleh lembaga pemerintah, baik eksekutif maupun legislatif yang diarahkan untuk tercapainya tujuan yang digariskan dalam keputusan kebijakan. Daniel A. Mazmanian dan Paul A. Sabatier (1983, 79) memberi empat kondisi sebagai prasyarat implementasi.

1. Output (keputusan) kebijakan dari agen-agen yang mengimplementasikan: tujuan-tujuan, sasaran-sasaran yang akan dicapai haruslah diterjemahkan ke dalam peraturan-peraturan yang senyatanya (riil); prosedur-prosedur yang baku dalam penyelesaian kasus-kasus individu.

2. Ketaatan kelompok-kelompok sasaran terhadap keputusan itu: keputusan untuk mematuhi hasil kebijakan dengan (a) kemungkinan bahwa ketidaktaatan (pelanggaran) akan diketahui dan dituntut; (b) sanksi yang tersedia untuk ketidaktaatan; (c) sikap kelompok sasaran mengenai legitimasi aturan-aturan yang fundamental; dan (d) biaya yang harus dipikul kelompok sasaran dari ketaatan dari kebijakan. 
3. Pengaruh dari hasil kebijakan tercapai kalau: (a) hasil kebijakan dari agen yang mengimplementasikan konsisten dengan tujuan kebijakan; (b) kelompok sasaran akhir patuh terhadap hasil kebijakan; (c) tak ada "subversi" yang serius terhadap hasil kebijakan atau pengaruh dari peraturan-peraturan yang bertentangan; dan (d) kebijakan memasukkan suatu teori kausalitas yang cukup memadai yang berkaitan dengan perubahan perilaku dalam kelompok sasaran untuk pencapaian tujuan yang ditetapkan.

4. Pengaruh yang dirasakan dari hasil kebijakan dari proses implementasi adalah pengaruh-pengaruh yang dirasakan dari hasil-hasil kebijakan, baik pengaruh yang dirasakan oleh kelompok pemilih maupun oleh penguasa. Dari pengaruh yang dirasakan ini, pada akhirnya akan membawa perubahan-perubahan dalam amanat undang-undang. Revisi besar dalam kebijakan seringkali dipandang sebagai tahap akhir proses implementasi

George C.Edward III (1980, 25) berargumen ada beberapa hal yang dapat mencerminkan keberhasilan implementasi kebijakan, diantaranya:

1. Komunikasi, hal ini menyangkut proses penyampaian informasi, transmisi kejelasan dan konsistensi informasi yang disampaikan.

2. Disposisi mengenai sikap dan komitmen dari para pelaksana terhadap program khususnya dari mereka yang menjadi implementer dari suatu kebijakan dan program, terutama adalah aparatur birokrasi.

3. Sumber daya, yang meliputi: (a) staf yang cukup (jumlahdan mutunya); (b) informasi yang dibutuhkan guna pengambilan keputusan; (c) kewenangan atau authority yang cukupdalam melaksanakan tanggung jawab; (d) fasilitas yang dibutuhkan dalam pelaksanaan.

4. Struktur birokrasi terdapatnya suatu SOP (Standart Operating Procedure) yang mengatur tata aliran pekerjaan dan pelaksana program.

Kajian ini dilakukan pada tahun 2017 di Provinsi Jambi, Sumatera Selatan, Kalimantan Selatan, Jawa Tengah, dan Jawa Barat. Dalam tulisan ini akan diuraikan bagaimana implementasi reforma agraria di Indonesia di 5 (lima) provinsi yang melaksanakan reforma agraria melalui berbagai program strategis antara lain redistribusi tanah, konsolidasi tanah, serta pendaftaran tanah yang diikuti oleh kegiatan pemberdayaan masyarakat (biasa dikenal dengan akses reform) lihat tabel 1 berikut :

\section{Tabel 1. Lokasi Sampel Penelitian}

\begin{tabular}{|c|c|c|c|c|c|}
\hline \multirow{2}{*}{ No } & \multirow{2}{*}{ Desa, Kecamatan, Kabupaten } & \multirow{2}{*}{ Program } & \multirow{2}{*}{ Tahun } & \multicolumn{2}{|c|}{ Jumlah bidang } \\
\hline & & & & Desa & Kabupaten \\
\hline 1 & Desa Pulau Mentaro, Kec. Kumpeh, Kab. Muaro Jambi & Redistribusi Tanah & 2016 & 134 & 1.000 \\
\hline 2 & Desa Banding, Kec. Beringin, Kab. Semarang & Redistribusi Tanah & 2014 & 275 & 380 \\
\hline 3 & Desa Rengaspendawa , Kec. Larangan, Kab. Brebes & Legalisasi Asset & 2016 & 100 & $4 \cdot 500$ \\
\hline 4 & Desa Telaga Langsat, Kec. Takisung, Kab. Tanah Laut & Redistribusi Tanah & 2017 & 125 & 125 \\
\hline 5 & Desa Roham Raya, Kec. Wanaraya, Kab. Barito Kuala & Redistribusi Tanah & 2014 & 480 & TAD \\
\hline 6 & Desa Jemah, Kec. Jati Gede, Kab. Sumedang & Redistribusi Tanah & 2016 & 1.000 & 1.000 \\
\hline 7 & Desa Sukamanah. Kec. Rongga, Kab. Bandung Barat & Redistribusi Tanah & 2016 & 300 & 300 \\
\hline 8 & $\begin{array}{l}\text { Desa KUD Mukti Jaya, Kec. Sungaililin ( } 5 \text { Desa), Kec. } \\
\text { Sungai Lilin, Kab. Musi Banyuasin }\end{array}$ & Konsolidasi Tanah & 2016 & 1.000 & 1.000 \\
\hline 9 & Desa Upang Marga, Kec. Makarti Jaya, Kab. Banyuasin & Redistribusi Tanah & 2016 & 89 & 988 \\
\hline
\end{tabular}


Berdasarkan tabel 1 terdapat sembilan kabupaten/kota yang telah melaksanakan program reforma agraria baik melalui program redistribusi tanah, konsolidasi tanah, dan legalisasiassetdari hasil tersebutsertipikat tanah telah dibagikan kepada seluruh masyarakat yang berhak dan telah mengacu pada Gambar 2. Skema Reforma Agraria dalam RPJMN. Untuk penerbitan sertipikat tidak ada persoalan, namun jika dikaitkan dengan pemberian akses reform, maka capaian yang ada belum optimal, sebab ada daerah yang berhasil dan ada yang belum selesai melaksanakan pemberian akses. Kondisi ini dikarenakan tugas Kantor Pertanahan yang utama adalah administrasi bidang tanah saja. Untuk aksesnya Kepala Kantor memiliki tantangan untuk membuat rancangan kegiatan mulai dari penjajakan dengan bupati dan kepala dinas terkait dan perusahaan yang memungkinkan membantu reforma agraria. Dari hasil pengamatan dan diskusi lapangan didapatkan data mengenai implementasi reforma agraria di lokasi sampel seperti pada tabel 2 berikut:

\section{Tabel 2. Ringkasan Hasil Pengumpulan Data}

\begin{tabular}{|c|c|c|c|}
\hline $\begin{array}{l}\text { Desa } \\
\text { Pulau Mentaro } \\
\text { Kabupaten } \\
\text { Muaro Jambi }\end{array}$ & $\begin{array}{l}\text { Penerima Aset } \\
\text { Reform } \\
\text { Petani padi, } \\
\text { jagung dan } \\
\text { kedelai }\end{array}$ & $\begin{array}{l}\text { Kendala Dan Keadaan Masyarakat } \\
\text { Penggunaan tanah: pertanian (saat surut), } \\
\text { penghasilan bersih rata-rata Rp.1.ooo.ooo/bulan } \\
\text { dengan masa tanam hanya dapat diusahakan } 6 \\
\text { bulan, karena periode genangan (pasang surut), } \\
\text { dan potensi masa tanam masih bisa ditingkatkan } \\
\text { dengan beberapa perlakuan tertentu. }\end{array}$ & $\begin{array}{l}\text { Akses Reform } \\
\text { Belum ada akses permodalan dari lembaga } \\
\text { keuangan/perbankan. } \\
\text { Sudah ada bantuan dari Dinas Pertanian } \\
\text { berupa sarana dan prasarana pertanian } \\
\text { walaupun belum terintegrasi dengan } \\
\text { program aset reform. }\end{array}$ \\
\hline $\begin{array}{l}\text { Banding } \\
\text { Kabupaten } \\
\text { Semarang }\end{array}$ & $\begin{array}{l}\text { Petani, buruh } \\
\text { tani, dan } \\
\text { pengrajin besek } \\
\text { bambu }\end{array}$ & \begin{tabular}{|l} 
Penggunaan tanah: pertanian kering/tegalan \\
dengan komoditas tanaman keras tahunan. \\
Mayoritas bekerja sebagai buruh tani, pengrajin \\
besek merupakan pekerjaan sambilan setelah \\
bertani. Pendapatan warga desa berkisar antara Rp. \\
750.ooo- Rp.1.ooo.ooo/bulan
\end{tabular} & $\begin{array}{l}\text { Sudah ada akses permodalan dari lembaga } \\
\text { keuangan/perbankan. } \\
\text { Program bantuan berupa bedah rumah } \\
\text { dari Kementerian Pekerjaan Umum dan } \\
\text { Perumahan Rakyat), walaupun tidak } \\
\text { terintegrasi dengan subyek penerima aset } \\
\text { reform. } \\
\text { Program pelatihan UKM dari pihak Pemda }\end{array}$ \\
\hline $\begin{array}{l}\text { Rengaspendawa } \\
\text { Kabupaten } \\
\text { Brebes }\end{array}$ & $\begin{array}{l}\text { Petani bawang } \\
\text { merah }\end{array}$ & $\begin{array}{l}\text { Penggunaan tanah: pertanian dengan komoditas } \\
\text { bawang merah. Kabupaten Brebes dikenal sebagai } \\
\text { penghasil bawang merah. }\end{array}$ & $\begin{array}{l}\text { Sudah ada akses permodalan dari lembaga } \\
\text { keuangan/perbankan tetapi cenderung } \\
\text { tidak melalui proses hak tanggungan. }\end{array}$ \\
\hline $\begin{array}{l}\text { Telaga Langsat } \\
\text { Kabupaten } \\
\text { Tanah laut }\end{array}$ & $\begin{array}{l}\text { Petani karet, } \\
\text { sawit dan } \\
\text { palawija }\end{array}$ & $\begin{array}{l}\text { Penggunaan tanah: pertanian dengan komoditas } \\
\text { tanaman karet, sawit, dan palawija, rata-rata luas } \\
\text { kepemilikan o,5-2 Ha. Masyarakat cenderung } \\
\text { merasa kekurangan sarana Jalan Usaha Tani (JUT) } \\
\text { dan kesulitan mendapatkan pupuk. } \\
\text { Hasil pertanian dijual kepada pengepul, untuk } \\
\text { sawit dan karet sudah terdapat pabrik kelapa sawit } \\
\text { milik perusahaan, untuk hasil palawija terserap } \\
\text { sangat sedikit, karena mekanisme pasar relatif } \\
\text { belum tersedia. }\end{array}$ & $\begin{array}{l}\text { Sudah ada akses permodalan dari lembaga } \\
\text { keuangan/perbankan, tetapi cenderung } \\
\text { tidak melalui proses hak tanggungan. } \\
\text { Sudah ada bantuan dari Dinas Pertanian } \\
\text { berupa benih padi, jagung dan kedele } \\
\text { setiap tahun, tapi belum terintegrasi } \\
\text { dengan program aset reform. }\end{array}$ \\
\hline $\begin{array}{l}\text { Roham Raya } \\
\text { Kabupaten } \\
\text { Barito Kuala }\end{array}$ & $\begin{array}{l}\text { Berkebun } \\
\text { singkong, sawit, } \\
\text { karet }\end{array}$ & $\begin{array}{l}\text { Masih dalam pengembangan budidaya singkong } \\
\text { dan Tapioka, karena tanah yang kurang produktif } \\
\text { dan kondisi dulu pohon karet warga yang pernah } \\
\text { terbakar }\end{array}$ & $\begin{array}{l}\text { Belum Ada Kegiatan Akses Reform Pasca } \\
\text { Legalisasi Aset. }\end{array}$ \\
\hline
\end{tabular}




\begin{tabular}{|l|l|l|l|}
\hline $\begin{array}{l}\text { Kemah } \\
\text { Sumedang }\end{array}$ & Petani padi dan & $\begin{array}{l}\text { Petani padi sudah lebih baik dan menghasilkan, } \\
\text { ditambah dengan produksi ikan kerambah, } \\
\text { sayangnya sejak waduk jatigede aktif aktifitas jaring } \\
\text { apung terhenti karena dilarang }\end{array}$ & $\begin{array}{l}\text { Belum Ada Kegiatan Akses Reform Pasca } \\
\text { Legalisasi Aset }\end{array}$ \\
\hline $\begin{array}{l}\text { Sukamanah } \\
\text { Kabupaten } \\
\text { Bandung barat }\end{array}$ & $\begin{array}{l}\text { Petani padi dan } \\
\text { palawija }\end{array}$ & $\begin{array}{l}\text { Masyarakat bertani padi dan palawija, potensi } \\
\text { penghasilan 8oo.ooo-1.50o.ooo. masih memerlukan } \\
\text { kemudahan akses dari desa ke luar yang masih } \\
\text { berbatu }\end{array}$ & $\begin{array}{l}\text { Belum Ada Kegiatan Akses Reform Pasca } \\
\text { Legalisasi Aset }\end{array}$ \\
\hline $\begin{array}{l}\text { KUD Mukti Jaya, } \\
\text { Kec. Sungaililin } \\
\text { (5 Desa) } \\
\text { Kabupaten } \\
\text { Banyuasin }\end{array}$ & Berkebun sawit & $\begin{array}{l}\text { Potensi sawit membuat masyarakat mendapatkan } \\
\text { dancome yang selaras dengan usia pohon sawit, } \\
\text { estimasi rata-rata penghasilan sawit dari awal } \\
\text { tanam sampai panen 2jt }\end{array}$ & $\begin{array}{l}\text { kondisi terakhir Replanting dan bantuan } \\
\text { permodalan sudah ada dari perkebunan } \\
\text { sawit }\end{array}$ \\
\hline $\begin{array}{l}\text { Upang Marga } \\
\text { Kabupaten Musi } \\
\text { Banyuasin }\end{array}$ & Petani padi & Potensi sawah (padi) menjadi unggulan di desa ini & $\begin{array}{l}\text { Belum Ada Kegiatan Akses Reform Pasca } \\
\text { Legalisasi Aset }\end{array}$ \\
\hline
\end{tabular}

Sumber: Olah data Puslitbang, 2017

Berdasarkan tabel 2 dan hasil pengamatan lapangan serta data-data hasil rekapitulasi nasional reforma agrarian masih belum optimal terlaksana di lokasi sampel, sebab persoalan mendasarnya terletak pada pasca sertipikasi tanah yang belum tentu ada kejelasan akses reform. Ada dua hal yang membuat akses itu sulit pasca sertipikasi; Pertama karena koordinasi antar Kantor Pertahanan dengan dinas atau Pemerintah Daerah dan pihak lain terhambat; Kedua masyarakatnya yang kurang proaktif (enggan) dalam pengusulan kegiatan pasca sertipikasi.

Sebagai ilustrasi di Jambi sudah digagas di Desa Pulau Mentaro, akan tetapi pasca pergantian Bupati, kegiatan lintas sektor yang digagas Kantor Pertanahan, dinas pertanian serta kelompok tani juga sedikit mengalami kendala. Kondisi di Brebes masih lebih baik tetapi bantuan modal (akses) reform berupa permodalan oleh Bank, sayangnya tidak ikuti oleh pembebanan hak tanggungan. Kondisi di Kabupaten Tanah Laut justru akses reform tersebut difasilitasi oleh Dinas Pertanian dua tahun setelah proses sertipikasi tanah selesai, ini berarti akses reform yang ada baru dua tahun kemudian. Kondisi ini mencerminkan bahwa aset dan akses reform tidak beriringan, terlaksana dengan baik. Kondisi di Kabupaten
Barito Kuala sampai sekarang belum ada kegiatan akses reform padahal redistribusi tanah nya ada sejak tahun 2014.

\section{Merancang Implementasi Reforma Agraria secara Holistik Integratif dan Sistematis.}

Pekerjaan besar yang menuntut komitmen bersama dan lintas kementerian patut membuat langkah strategis, hal ini menyangkut siapa melakukan apa dan bagaimana. Michael Lipton (2009, 178) berargumen untuk membuat reforma agraria itu bisa berhasil, setidaknya ada 10 (sepuluh) hal yang perlu diurus oleh pemerintah secara terpimpin dan sistematis, yakni: (1) mandat konstitusional; (2) regulasi perundang-undangan dan penegakannya; (3) organisasi pelaksana reforma agraria; (4) sistem administrasi agraria; (5) pengadilan dan mekanisme penyelesaian konflik; (6) desain rencana dan evaluasi; (7) pendidikan dan latihan; (8) pembiayaan; (9) pemerintahan daerah; dan (10) partisipasi masyarakat, terutama organisasi rakyat pedesaan.

Dalam konteks di Indonesia kondisi seperti pendapat Lipton belum menjadi sebuah textbook (sistematis, integratif, dan holistic) dalam pelaksanaannya. Perlu mendapat 
catatan penting sebagai kementerian yang memiliki produk layanan berupa sertipikat, disisi lain ada beberapa langkah yang perlu diambil dalam mempercepat akses reform pasca sertipikasi. Komponen penting dalam pelaksanaan Program Pemberdayaan Masyarakat Pasca Legalisasi Aset, meliputi:

1. Organisasi pembentukan kelompok masyarakat yang akan diberdayakan melalui akses reform berdasarkan bidang usaha dan kebutuhan yang diperlukan.

2. Pembangunan infrastruktur meliputi Pembangunan sarana dan prasana untuk menunjang kegiatan akses reform bagi masyarakat, antara lain: jalan, komunikasi, irigasi, dan lain-lain. Kegiatan ini melibatkan pihak Instansi/SKPD dan Pemangku Kepentingan terkait.

3. Pembinaan dan Pelatihan untuk Pemberian pembinaan dan pelatihan-pelatihan khusus yang dibutuhkan masyarakat untuk meningkatkan keterampilan dan kemampuan dalam menjalankan aktivitas usaha, produksi, dan lain-lain dalam rangka mengembangkan/meningkatkan usaha.

4. Permodalan Akses permodalan yang dibutuhkan untuk pembiayaan dalam rangka peningkatan dan pengembangan usaha, antara lain melalui penjaminan sertipikat hak atas tanah sebagai agunan untuk memperoleh kredit perbankan.

5. Pemasaran dan Tata Niaga, bagaimana Fasilitasi pemasaran/penyaluran produk sebagai bahan baku bagi industri-industri hilir. Dalam rangka pelaksanaan Program Pembedayaan Masyarakat Pasca Legalisasi Aset tersebut diperlukan langkah-langkah sebagai berikut:

a. Pemetaan sosial/inventarisasi potensi fisik lokasi, sosial dan ekonomi masyarakat ;

b. Analisis potensi yang ada pada masyarakat ; c. Pendampingan dalam rangka Pengorganisasian kelompok masyarakat Penyusunan rencana usaha masyarakat

d. Fasilitasi dan kerjasama dengan instansi/SKPD dan pemangku kepentingan terkait lainnya pelaksanaan rencana usaha sebagai wujud pemberian akses ke sumbersumber ekonomi.

e. Pendampingan kepada kelompok masyarakat dalam pelaksanaan pemberian akses oleh instansi/SKPD dan pemangku kepentingan terkait lainnya.

f. Pemantauan dan evaluasi terhadap pelaksanaan pemberian akses oleh instansi/SKPD dan pemangku kepentingan terkait lainnya. Untuk melaksanakan langkah-langkah tersebut diatas, perlu di alokasikan anggaran yang cukup dan memadai, sehingga Program Pemberdayaan Masyarakat Pasca sertipikasi dapat dilaksanakan sesuai dengan rencana dan tepat sasaran.

Point 1-5 di atas sebaiknya mulai digagas di awal utamanya bagi masyarakat penerima program reforma agraria dengan sinergi dengan pemerintah daerah harus juga terpetakan di desa tersebut. Potensi utama untuk penunjang akses reformnya seperti apa dan sebelum melangkah, ada hubungan sinergi antara Kantor Pertanahan dengan Pemerintah Daerah agar menggerakkan kegiatan ekonomi atau program unggulan daerah di desa-desa yang tanahnya ada program sertipikasi redistribusi tanah atau legalisasi asset.

\section{E. Hambatan antar kelembagaan}

Konsep kebijakan di bidang Agraria sangat menarik pada tingkatan gagasan, akan tetapi pada tingkatan implementasi sangat sulit direalisasi, karena butuh bantuan banyak pihak. 
Satu sisi pemerintah mendorong dengan kuat, disisi yang lain secara ekonomi negara tidak memiliki kemampauan yang cukup untuk terus berada dalam posisi terdepan dalam penggerak ekonomi, perlu campur tangan para pemodal untuk berpartisipasi. Kondisi ini memerlukan pencermatan dan perhitungan yang dapat menguntungkan dan saling berkolaborasi, sebab tanpa didukung formulasi yang tepat akan berakibat penguasaan segelintir pihak terhadap pihak yang lainnya. Fakta ini tidak bisa disalahkan reforma agraria ideal masih terkendala kemauan politik pimpinan tertinggi. Ada dua hal menurut penulis, pertama, belum pulihnya esensi UUPA sebagai aturan dasar mengelola sumber-sumber agraria yang bukan tanah semata; kedua, makna Reforma agraria yang masih identik dengan lembaga pertanahan. Penulis ingin mengutarakan bahwa reforma agraria salah satu upaya peningkatan perekonomian masyarakat berbasis tanah yang mewajibkan seluruh kementerian lembaga yang memiliki fungsi peningkatan ekonomi untuk mengadopsi dan mensinergikan diri, tentu mekanisme dan aturan mainnya tetap perlu disepakati dengan aturan hukum yang jelas dan sistematis dikoordinasikan oleh Kementerian Koordinator Bidang Perekonomian.

Berdasarkan hasil di lapangan mencerminkan beberapa hal yang perlu diperhatikan lokasi-lokasi tanah redistribusi tanah perlu untuk mendapat perhatian lebih serius dan secara komprehensif, sebab pada lokasi ini secara geografis jauh dari pusat ekonomi dan pusat pertumbuhan serta masyarakatnya belum sepenuhnya memiliki interaksi dengan perbankan. Sehingga reforma agraria lebih diarahkan untuk pembukaan askes ekonomi (permodalan) dan tata niaga. Desa sukamanah dan Desa Jemah serta Desa Upang Marga perlu mendapatkan perhatian khusus (program redis yang telah dilakukan tahun 2016).
Pada lokasi tanah-tanah program Prona dan KonsolidasiTanahmasyarakatnyasecaraekonomi lebih baik, karena aksesibilitas dan wilayahnya lebih dekat dengan pusat pertumbuhan sehingga tingkat ekonominya lebih berkembang.

Desa yang berada dekat dengan wilayah kebun atau wilayah desa, dekat dengan pusat pertumbuhan lebih mudah mendapatkan akses reform meski di prakarsai oleh BPN atau tidak ada prakarsa BPN. Tingkat pengetahuan akan informasi akses ekonomi dan peningkatan keterampilan membutuhkan sosialisasi yang intens kepada masyarakat, terkadang pasca mendapat sertipikat, masyarakat mengetahui sertipikat tanah bisa diagunkan di bank, tetapi bagaimana administrasi/persyaratan dan kewajiban dalam proses pengajuan perlu digalakkan kembali.

\section{Gambar 3. Skema Kelompok Kerja Reforma Agraria Lintas Kementerian}

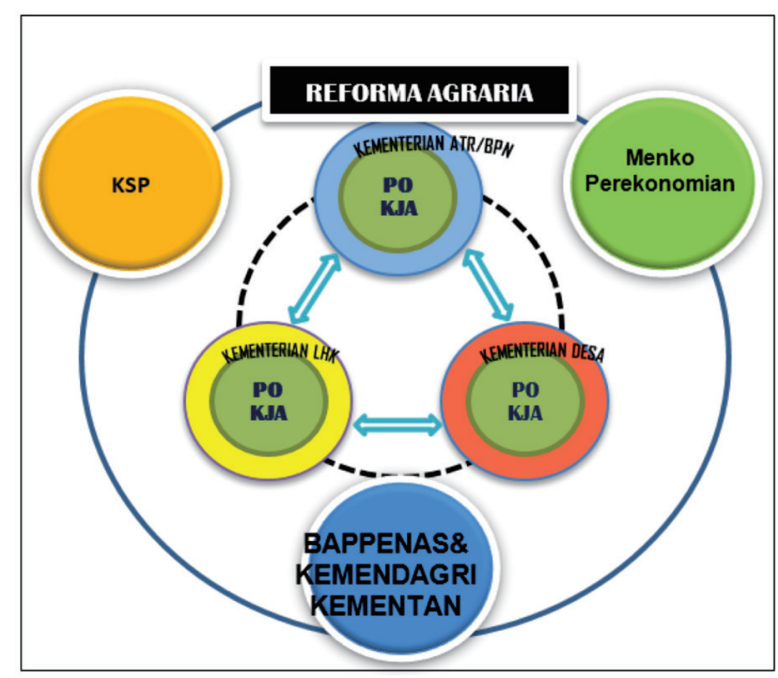

Sumber: Paparan Joko Heriyadi dalam Seminar Akhir Penelitian Implementasi Reforma Agraria Tahun 2017, diselenggarakan oleh Puslitbang Kementerian ATR/BPN Tanggal 9 November 2017 di Jakarta.

Mengacu pada gambar di atas konsen Kementerian ATR/BPN dan Kementerian LHK hanya membuat bank data yang sinergi lokasi desa mana yang representatif dalam kategori reforma agraria, baik yang ada di kawasan maupun luar kawasan. Kementerian Desa dan Pertanian lebih spesifik memberikan basis data 
keunggulan wilayah desa-desa. Bappenas dan Kemenko perekonomian mencoba membuat skema anggaran agar penggunaannya secara faktual mengarah pada database, bila memungkinkan Kemenko menggandeng peran swasta. KSP dan Kementerian Dalam Negeri mendorong agar supaya pemerintah daerah tertarik untuk mengawal kegiatan tersebut di tingkat lokal. Sinergi itu bukan sebatas koordinasi tetapi sinergi anggaran dan program lintas kementerian merupakan prasyarat mempercepat reforma agraria. Setelah itu reforma agraria bukan program unggulan kementerian ATR/BPN, tetapi milik bangsa Indonesia. Sebagai salah satu pilihan langkah untuk mensejahterakan masyarakat berbasis sumber-sumber agraria.

Reforma agraria diprediksi tidak akan bisa tercapai dalam waktu 2,5 tahun jika skema yang dipakai saat ini masih digunakan. Karena belum ada peraturan yang bisa mengakomodir kepentingan seluruh unit kementerian yang dalam koridor peningkatan kesejahteraan masyarakat serta peningkatan akses perekonomian masyarakat. Gagasan konsep reforma agraria ini hendaknya tertuang dalam sebuahaturanyang kompatibel dengan segenap kementerian yang ada. Mulai Fase penentuan lokasi sampai produk yang dihasilkan terukur secara seksama dan memberikan dampak yang signifikan. Pengamatan secara seksama dan periodik diperlukan untuk mengukur sejauh mana reforma agraria ini dinyatakan berhasil.

Gambar 4. Kebijakan dan Arah Perubahan Reforma Agraria Ilustrasi penulis terhadap kebijakan reforma agraria secara makro

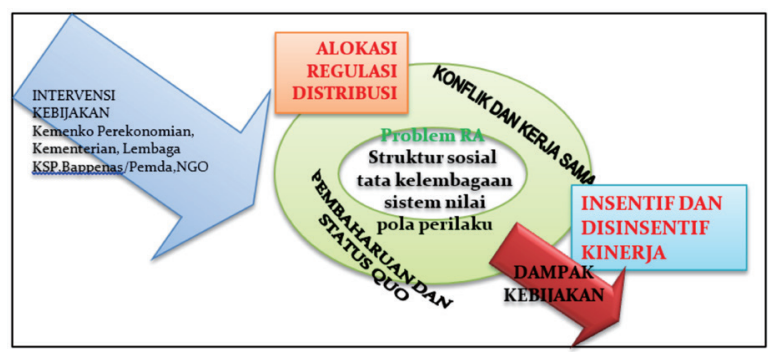

Kendala dalam sebuah kebijakan adalah hal biasa, karena setiap kebijakan merupakan sebuah langkah strategis, khususnya berkaitan dengan alokasi, distribusi, dan redistribusi resources yang terbatas. Konsekuensi ini membawa dampak siapa mendapat apa dan bagaimana. Sehingga jika berdasarkan pemikiran Merilee Grindle (1980, 83) maka kebijakan reforma agraria di Indonesia ada gap yang terjadi antara content adan context of policy jarak yang terjadi disini berkaitan komitmen dari stakeholders yang ada, dapat diilustrasikan sebagai berikut:

\section{Gambar 5. Implementasi Kebijakan dan Arah Perubahannya Menurut Grindle}

\begin{tabular}{|l|l|}
\hline Content of Policy/Substansi \\
Kepentingan (interest) \\
Keuntungan/manfaat \\
Luas perubahan \\
Tingkatan Pengambil \\
Keputusan \\
Pelaksanaan Program \\
Sumberdaya
\end{tabular}

\section{B. Kesimpulan}

\section{Kesimpulan}

a.) Implementasi Reforma Agraria belum optimal, karena kurangnya dukungan dari berbagai stakeholders terkait, sebab program ini akan berdampak besar jika didukung oleh kementerian lain yang memiliki sumber pendanaan untuk peningkatan potensi ekonomi masyarakat, jika hanya internal BPN hanya sebatas pensertipikatan tanah masyarakat;

b.) Pembagian peran dan fungsi dalam koridor akses reform memerlukan landasan konseptual yang konkrit dan jelas, berupa peraturan yang diterima semua pihak, disini komitmen politik dalam nawacita mendapat tantangan untuk menyusun aturan yang disepakati lintas kementerian/ lembaga; 
c.) Keberhasilan reforma agraria mutlak memerlukan sinergi antara Pemerintah Pusat, Pemerintah Daerah, masyarakat.

\section{Rekomendasi}

a.) Perlu disusun sebuah peraturan terkait definisi reforma agraria dan tugas, peran serta fungsi para pihak yang terlibat.

b.) Ada baiknya penyerahan sertipikat juga diikuti dengan pemberian akses untuk usaha masyarakat lebih produktif.

c.) Ada baiknya pembebasan biaya administrasi dalam proses hak tanggungan sehingga masyarakat lebih terbantu, utamanya penerima akses reform yang ketegori miskin.

d.) Adanya peningkatan sinergitas antara Direktorat Landreform dengan Pemberdayaan Masyarakat agar kegiatan pasca pensertipikatan di tahun berikutnya diberi akses reform, mengingat pada lokasi redistribusi tanah memiliki kencenderungan sebagai daerah tertinggal.

e.) Perlu adanya kerja bersama yang mulai terpetakan. hendaknya memaknai peningkatan pereknomian pasca kegiatan reforma agraria, bukan menjadi tugas kementerian yang mengurus pertanahan semata, akan tetapi dimaknai sebagai kerja kementerian lembaga terkait untuk ikut andil memberikan dampak ekonomi pasca aset tanah masyarakat terlegalkan.

\section{Ucapan Terima Kasih}

Penulis mengucapkan terima kasih kepada Kepala Pusat Penelitian dan Pengembangan Kementerian ATR/BPN beserta staf, segenap narasumber, informan dan responden yang tidak bisa disebutkan namanya satu per satu.

\section{Daftar Pustaka}

A.P. Parlindungan 1980, Komentar atas undang-undang pokok agraria, alumni Bandung.

Agus Salim 2001, Teori dan paradigma penelitian sosial: pemikiran norman $k$. denzin $\mathcal{E}$ egon guba dan penerapannya, Penerbit PT. Tiara Wacana Yogya.

Amir Santoso 1998. Analisis kebijakan publik, jurnal ilmu politik Vol.3, Jakarta, PT. Gramedia.

Daniel A. Mazmanian dan Paul A. Sabatier 1983. Implementation and public policy IIIinois: Scott Foresman and Company

George C.Edward III 1980, Implementing public policy, congressional quarterly inc. Washington D.C.

Grindle, Merilee, S. (ed) 1980, Politics and policy implementation in the third world, Princeton University Press, New Jersey

Lipton, Michael 2009, Land reform in developing countries: property rights and property wrongs (Routledge Priorities in Development Economics). London.

Mubyarto 1978, Masalah petani kecil dan strategi pembangunan pedesaan di jawa, agro-ekonomika. 9 (8).

Nurlinda, Ida 2015, Membangun struktur hukum reforma agraria untuk mewujudkan keadilan agraria. Orasi pengukuhan Guru Besar Fakultas hukum Universitas Padjajaran.

Ramadhiani, A 2016, Reforma agraria bukan tentang bagi-bagi tanah, Kompas, 13 April.

Risnarto 2008, Reforma agraria politik mensejahterakan rakyat, bunga rampai : dari landreform ke landreform plu. Jakarta. Pusat Penelitian dan Pengmebangan Badan Pertanahan Nasional Republik Indonesia. 
Sembiring, Julius 2016, Hak menguasai negara atas sumber daya agraria Jurnal Bhumi Vol. 2 No. 2 STPN Press. Yogyakarta

Setiawan, Bonnie 1997, Reformasi agraria, perubahan politik, dan agenda pembaharuan agraria di indonesia, Konsorsium Pembaruan Agraria dan lembaga. Penerbit FEUI, Jakarta.

Shohibuddin, M dan Nazir Salim 2012, Pembentukan kebijakan reforma agraria 2006-2007 bunga rampai perdebatan. Sekolah Tinggi Pertanahan Negara Press, Yogyakarta.

Winoto, Joyo 2009, Strategi kebijakan pertanahan nasional dalam perspektif politik ekonomi pembangunan pertanian dan pedesaan. Makalah Utama dalam Prosiding Semiloka Nasional tanggal 2223 Desember 2008. Bogor. Departemen Ilmu Tanah dan Sumberdaya Alam, Fakultas Pertanian IPB.

Wiradi, Gunawan 1999, Reforma Agraria dalam menghadapi era globalisasi. makalah ringkas dalam seminar nasional: pemberdayaan petani melalui reforma agraria dalam menghadapi era globalisasi tanggal 5 Agustus 1999. Jakarta: Himpunan Kerukunan Tani Indonesia (HKTI) dan Kantor Menteri Negara Agraria dan Badan Pertanahan Nasional.

Yin, Robert 1994 Case study research: design and method, second edition, Applied Social Research Methods Series Volume 5, Sage Publications, London.

\section{Dokumen, Makalah dan Surat kabar}

Anonim tt, "Nawa Cita", 9 Agenda Prioritas Jokowi-JK, 2014-2019. Perpustakaan Presiden Republik Indonesia.

Direktorat Jenderal Penataan Agraria 2017, Materi Pembukaan Pendidikan dan Pelatihan Penataan Agraria. Jakarta:
Kementerian Agraria dan Tata Ruang/ Badan Pertanahan Nasional. 31 Slide.

Direktorat Jenderal Penataan Agraria, Direktorat Landreform 2016. Petunjuk Pelaksanaan Kegiatan Landreform. Jakarta: Kementerian Agraria dan Tata Ruang/ Badan Pertanahan Nasional. ${ }_{11} \mathrm{Hlm}$.

Direktorat Jenderal Penataan Agraria, Direktorat Landreform 2017. Kebijakan Agraria dan Tata Ruang (Kebijakan Landreform). Bahan Paparan Disampaikan pada Pendidikan dan Pelatihan Penataan Agraria. Jakarta : Kementerian Agraria dan Tata Ruang/ Badan Pertanahan Nasional. 49 slide.

Djalil, Sofyan A 2016, Menteri Agraria dan tata Ruang/ Kepala Badan Pertanhan Nasional Disampaikan pada Seminar Nasional dalam Rangka Hari Agraria dan Tata Ruang Nasional Jakarta, 25 Oktober 20 slide.

Heriyadi, PJoko 2017, Seminar Akhir Penelitian Implementasi Reforma Agraria Tahun 2017 diselenggarakan Oleh Pusat Penelitian dan Pengembangan Kementerian Agraria dan Tata Ruang /BPN Tanggal 9 November 2017 di Jakarta, Slide 7 dari 47

Kementerian Agraria dan Tata Ruang/Badan Pertanahan Nasional, Petunjuk Pelaksanaan Kegiatan Landreform 2016

Pusat Penelitian dan Pengembangan 2017, Draft Road Map Puslitbang. Kementerian Agraria dan Tata Ruang/Badan Pertanahan Nasional. 49 slide. Jakarta.

Pusat Penelitiandan Pengembangan 2017, Seminar Akhir Penelitian Implementasi Reforma Agraria Tanggal di Jakarta 47 Slide.

Rachman, Noer Fauzi 2016, Makalah Arah Kebijakan Reforma Agraria Kementerian Agraria dan Tata Ruang/ Badan Pertanahan Nasional dalam seminar hari agraria dan tata ruang nasional 25 Oktober. 